\title{
Justification for creating a mobile complex to assess electric energy loss in power transformers during the operation process
}

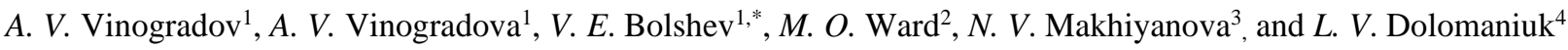 \\ ${ }^{1}$ Federal Scientific Agroengineering Center VIM, Moscow, Russia \\ ${ }^{2}$ Damascus University, Damascus, Syria \\ ${ }^{3}$ Orel State Agrarian University, Orel, Russia \\ ${ }^{4}$ Kazan State Power Engineering University, Kazan, Russia
}

\begin{abstract}
The paper analyzes the statistical data on the transformers of the Kromsky branch of Oreloblenergo OJSC including the average lifetime of the transformers and no-load losses measured in accordance with the requirements of Russian standard GOST 3484.1. The analysis indicates that the declared passport data differ from the measured data. There is also the analysis of technical solutions to improve the power transformer design including to development of new types of electrical steel used in transformer cores, superconducting materials for winding. The article gives an understanding of the advantages and disadvantages of using these technologies as well as the possible reduction of electrical losses. In conclusion there is the justification for creating the mobile measuring complex to assess electric energy loss in power transformers during operation without disconnecting the load. The paper describes the result achieved using such a mobile measuring complex along with the economic effect of creating the project.
\end{abstract}

\section{Introduction}

Currently, a large number of power transformers with a standard service life are in operation in rural distribution networks [1]. No-load losses increase during operation of power transformers. They occur as a result of magnetic system aging, changes in the metal structure, deterioration of interlayer insulation, weakening of the transformer core pressing [2-5]. Previously it was assumed that no-load losses for the entire service life (35-40 years) in serviceable transformers increased by no more than $5 \%$ compared with the results obtained during factory tests. The works $[6,7]$ show that, in reality, the no-load losses in transformers increases to a greater degree. These losses are a source of increased costs for electric grid organizations to pay for electric power losses. At the same time, the difference between actual and calculated idle losses refers to commercial losses. It does not allow to justify a higher electricity tariff and also directs the grid organization in the wrong direction to search for lost kilowatt hours. So, in fact, technical losses in transformers are commercial.

Existing methods to assess the no-load losses of power transformers do not allow to conduct this survey without disconnecting the load [1]. Therefore, it is necessary to develop new methods for estimating noload losses making it possible to carry out a rapid assessment without removing the load from the transformer, therefore, avoiding unreasonable the power supply interruptions for electricity consumers.

\section{Statistics}

To assess the statistical data on the transformers of the Kromsky branch of Oreloblenergo OJSC, the no-load losses of transformers were measured in accordance with the requirements of GOST 3484.1. The obtained data are shown in table 1 . Also, table 1 shows the passport values of the transformer no-load losses.

The analysis of the presented statistical data shows that the average lifetime of the transformers is 31.6 years, the no-load losses of the operating power transformers exceed the passport average by $23 \%$. Their difference must be taken into account when calculating the normative level of electric power losses in power networks [6]. Increasing the no-load losses by $10 \%$ will increase the total losses in transformers by $1-2 \%$. Most rural power transformers operate at low loads, so the share of no-load losses in the total losses of transformers is significant [1]. In this case, the dependence of the increase in losses on the service life is not always directly observed; in some cases, newer transformers have a greater excess of no-load losses than the old ones. This suggests the need for rapid assessments of no-load losses in transformers to obtain more objective information as compared to that obtained by means of simulation.

\footnotetext{
*Corresponding author: vadimbolshev@gmail.com
} 
Table 1. No-load losses of transformers operated in the Kromsky branch of Oreloblenergo OJSC.

\begin{tabular}{|c|c|c|c|c|c|c|}
\hline \multirow{2}{*}{ Transformer type } & \multirow{2}{*}{$\begin{array}{c}\text { Year of } \\
\text { manufacture }\end{array}$} & \multirow{2}{*}{$\begin{array}{c}\text { Lifetime, } \\
\text { years }\end{array}$} & \multirow{2}{*}{$\begin{array}{c}\text { Overhaul } \\
\text { year }\end{array}$} & \multicolumn{2}{|c|}{ No-load losses, $\mathbf{k W}$} & \multirow{2}{*}{$\begin{array}{c}\text { Increased } \\
\text { losses after } \\
\text { overhaul, \% }\end{array}$} \\
\cline { 5 - 6 } & & & & passport & maintenance & \\
\hline TM-400/10/0.4 & 1980 & 35 & 1996 & 1.08 & 1.4 & 29.62 \\
\hline TM-160/10/0.4 & 1976 & 39 & 1999 & 0.54 & 0.62 & 14.81 \\
\hline TM-250/10/0.4 & 1989 & 26 & 2008 & 1.05 & 1.2 & 14.28 \\
\hline TM-160/10/0.4 & 1984 & 31 & 2003 & 0.54 & 0.73 & 35.18 \\
\hline TM-400/10/0.4 & 1980 & 35 & 1999 & 1.08 & 1.47 & 36.11 \\
\hline TM-160/10/0.4 & 1987 & 28 & 2006 & 0.54 & 0.61 & 12.96 \\
\hline TM-160/10/0.4 & 1989 & 26 & 2008 & 0.54 & 0.7 & 29.62 \\
\hline TM-400/10/0.4 & 1981 & 34 & 2009 & 1.08 & 1.34 & 24.07 \\
\hline TM-400/10/0.4 & 1983 & 32 & 2012 & 1.08 & 1.17 & 8.33 \\
\hline TM-400/10/0.4 & 1981 & 34 & 2014 & 1.08 & 1.2 & 11.11 \\
\hline TM-160/10/0.4 & 1987 & 28 & 1996 & 0.54 & 0.74 & 37.03 \\
\hline
\end{tabular}

\section{Review of ways to improve the design of transformers}

Various authors, scientific and production teams are working to improve the design of power transformers in order to reduce no-load losses $[8,9]$. Thus, the quality of electrical steel is continuously improved. For widely used grades of cold-rolled, oriented, with high magnetic permeability of steel with high silicon content, the level of specific losses of about $1.05-1.10 \mathrm{~W} / \mathrm{kg}$ at $50 \mathrm{~Hz}$ and $1.7 \mathrm{~T}$ is achieved. The best grades have a specific loss of about $0.85 \mathrm{~W} / \mathrm{kg}$. The use of sheets of smaller thickness reduces also the loss. Thus, steel with a thickness of 0.23 $\mathrm{mm}$ has a specific loss of $20 \%$ less than steel with a thickness of $0.3 \mathrm{~mm}[10,11]$. An effective technology for processing steel is laser scribing with a decrease in the length of oriented crystals. In this way, the level of specific losses of $0.5 \mathrm{~W} / \mathrm{kg}$ was obtained in combination with the use of plates of reduced thickness. A decrease in specific losses to $0.3 \mathrm{~W} / \mathrm{kg}$ is predicted with a decrease in sheet thickness to $0.18 \mathrm{~mm}$ [12].

Recent developments in the field of transformer design are based on the use of steel with a silicon content of 3\% having low magnetostriction and allowable losses. The use of reduced induction in the core allows not only to reduce losses in it, but also to significantly reduce the noise level from the transformer. The decision is made on the basis of technical and economic considerations $[13,14]$.

A fundamentally new way to reduce losses in a transformer is the use of superconducting materials for winding. Low-temperature superconductors, on which the first prototypes of transformers were made, are not competitive with high-temperature superconductors (HTSC) $[15,16]$. The progress in the creation of HTSC materials makes it possible to consider the undoubted economic prospects of such developments. From 1992 to
2000 the price of HTSC materials has decreased by 20 times [17]. The advantages of HTSC transformers are the following: reduction of load losses by $90 \%$, reduction of mass to $40 \%$, limitation of short-circuit currents, reduction of reactance, good overload capacity (up to $100 \%$ long), low noise level. Such a transformer with mastered production is $20 \%$ cheaper than a conventional transformer of the same capacity [17]. All the above solutions can reduce no-load losses in newly created transformers. The problem of excessive losses in the electrical transformer networks installed at the enterprise remains unsolved.

\section{Justification for creating the mobile measuring complex to assess electric energy loss in power transformers}

At the same time, today there are no measuring complexes or devices on the market that allow to assess the no-load losses in power transformers during operation without disconnecting the load. Method of measurement and electrical laboratory developed by Tsitorin A.N. [1] allows to assess no-load losses during operation, but requires the disconnected load for the time of measurements. This leads to undersupply of electricity to consumers.

It is necessary to create a mobile measuring complex suggesting the possibility to assess no-load losses, shortcircuit losses in power transformers without disconnecting the load. This will achieve the following results:

- reducing energy losses in power transformers and reducing the cost of paying for them by identifying and replacing transformers with excessive no-load losses;

- improving the organization of work on the power transformer replacement through effective planning and distribution of investments; 
- improving the accuracy of calculating the electricity loss in power transformers and the correctness of the classification of losses as technical and commercial;

- making it possible to rely on real measurements and assessment of electric power losses when calculating electricity tariffs;

- prevention of unjustified power supply interruptions to consumers and reduction of losses from electricity undersupply.

The economic effect of the project to create such a complex consists of many of the above components. One of the main components is the reduction of electric power losses in power transformers due to the replacement of transformers with increased no-load losses. For example, hundred transformers with a power of $25 \mathrm{kVA}$, which are higher than the passport ones by $50 \%$, give the following increase in electric power losses during a year one (equation (1)):

$$
\Delta \mathrm{P}_{N L L}=N \times T \times\left(\Delta \mathrm{P}_{N L L \text { (old trans.) }}+\Delta \mathrm{P}_{N L L \text { (new trans. })}\right)
$$

where $N$ is number of transformers, pcs (100 pcs); $T$ is time period, h (a year); $\Delta P_{N L L \text { (old trans.) - no-load }}$ power loss in old transformer, $\mathrm{kW} \cdot \mathrm{h} ; \Delta P_{N L L}$ (new trans.) - no-load power loss in new transformer, $\mathrm{kW} \cdot \mathrm{h}$.

$$
\Delta \mathrm{P}_{N L L}=100 \times 8760 \times(0.195+0.13)=56940 \mathrm{~kW} \cdot \mathrm{h}
$$

This value of losses requires an additional payment in the amount of 228 thousand rubles (3615.52 \$), at a cost of electricity of 4 rubles $/ \mathrm{kWh}(0.063 \$ / \mathrm{kWh})$, which is equivalent to the cost of purchasing three transformers at a cost of each more than 60 thousand rubles $(951.45$ $\$$ ). This "effect on volume" can be used when planning replacements for transformers whose service life is coming to an end. At present, the replacement of transformers according to the criterion of the no-load losses level is not carried out.

There is an effect when replacing single transformers with not exhausted service life, but with the no-load losses exceeding passport values. Calculations show that the profitability of transformer replacement grows with increasing power. Thus, it is cost-effective to replace transformers when no-load losses are exceeded with respect to passport by $70 \%$, if their power is $25 \mathrm{kVA}$, and by $40 \%$, if their power is $100 \mathrm{kVA}$.

\section{Conclusions}

1. The analysis of no-load losses in transformers operated by the Kromsky branch of Oreloblenergo OJSC indicates that the declared passport data differ from the measured data. The no-load losses increase by 100 percent or more with an increase in the lifetime of power transformers. The average excess of no-load losses over passports was more than $50 \%$.

2. Various authors have developed a large number of technical solutions to improve the power transformer design, but the problem to assess no-load losses in installed transformers without disconnecting them from the load remains unresolved.

3. The authors substantiate the need to create a mobile measuring complex to assess electric power losses in power transformers with load. The use of such a complex is economically feasible by reducing electricity losses in power transformers and reducing the cost of paying for them by identifying and replacing transformers with excessive no-load losses, preventing unreasonable power supply interruptions to consumers and reducing power supply outage.

\section{References}

[1] A. Cicorin, Ocenka poter' holostogo hoda v sel'skih silovyh transformatorah pri ih ehkspluatacii [Estimation of no-load losses in rural power transformers during their operation]. doctoral dissertation (Russia) (2012)

[2] N.El. Wakil, N.C. Chereches, J. Padet, Numerical study of heat transfer and fluid flow in a power transformer. International Journal of Thermal Sciences $\quad \mathbf{4 5 ( 6 )}, \quad 615-26 \quad$ DOI: 10.1016/j.ijthermalsci.2005.09.002 (2006)

[3] J.M. Mufuta, E. Van den Bulck, Modelling of the mixed convection in the windings of a disc-type power transformer. Applied Thermal Engineering 20(5), 417-37 DOI: 10.1016/S1359-4311(99)00034-4 (2000)

[4] G. Swift, T.S. Molinski, W. Lehn, A fundamental approach to transformer thermal modeling. I. Theory and equivalent circuit. IEEE transactions on Power Delivery 16(2), 171-5 DOI: 10.1109/61.915478 (2001)

[5] G. Swift, T.S. Molinski, R. Bray, R. Menzies, A fundamental approach to transformer thermal modeling. II. Field verification. IEEE Transactions on Power Delivery 16(2), 176-80. DOI: 10.1109/61.915479 (2001)

[6] S.A. Tsyruk, E.A. Kireeva, Povyshenie ekspluatacionnoj nadezhnosti silovyh transformatorov, otrabotavshih normativnyj srok sluzhby [Improving the operational reliability of power transformers that have completed their standard service life]. Promyshlennaya energetika, 3, 11-15 (2008)

[7] Yu.B. Kazakov, V.Y. Frolov, A.V. Korotkov, Metodika opredeleniya moshchnosti poter' holostogo hoda transformatorov s razlichnym srokom sluzhby [Method of determining the power loss of idling transformers with different service life]. Bulletin of the Ivanovo State Energy University 1, 1-5 (2012)

[8] R.M. Del Vecchio, B. Poulin, M.E. Feeney, P.T. Feghali, D.M. Shah, R. Ahuja, D.M. Shah, Transformer design principles: with applications to core-form power transformers. (CRC press) (2001)

[9] J.C. Olivares, Y. Liu, J.M. Cañedo, R. Escarela-Pérez, J. Driesen, P. Moreno, Reducing losses in distribution transformers. IEEE transactions on power delivery $\quad \mathbf{1 8 ( 3 )}, \quad 821-6 . \quad$ DOI: 10.1109/TPWRD.2003.813851 (2003) 
[10] P. Beckley, Modern steels for transformers and machines. Power Engineering Journal 13(4), 190200. DOI: $10.1049 /$ pe: 19990403 (1999)

[11] V. Janardhan, D. Galloway, Thinking about the box: Ten ways to mitigate distribution transformer losses. ElectricLight\& Power 79(10), (2001)

[12] R. Baehr, Transformer technology state-ofthe-art and trends of future development. ELECTRACIGRE 13-9 (2001)

[13] B.A. Alekseev, V.E. Vorotnitsky, $O b$ utochnenii normativov $i$ snizhenii poter' elektroenergii $v$ silovyh transformatorah s uchetom sroka ih sluzhby [On specification of standards and reduction of electricity losses in power transformers, taking into account their service life] [Internet] Avialable from: http: // portalenergetika. com / articles / ob_utochnenii_normativov_i_snijenii_poter_elektroener gii_v_silovyih_transformatorah_s_uchetom_sroka_ih_sl ujbyi_24

[14] S. Taguchi, T. Yamamoto, A. Sakakura, New grain-oriented silicon steel with high permeability "ORIENTCORE HI-B". IEEE Transactions on $\begin{array}{llll}\text { Magnetics } & \mathbf{1 0}(2), & 123-7 . & \text { DOI: }\end{array}$ 10.1109/TMAG.1974.1058316 (1974)

[15] C.T. Reis, S.P. Mehta, B.W. McConnell, R.H. Jones, Development of high temperature superconducting power transformers. In 2002 IEEE Power Engineering Society Winter Meeting. Conference Proceedings (Cat. No. 02CH37309) 1, 151-156. DOI: 10.1109/PESW.2002.984977 (2002)

[16] A.P. Malozemoff, The power grid and the impact of high-temperature superconductor technology: An overview. In Superconductors in the Power Grid (Woodhead Publishing) 3-28 (2015)

[17] V.V. Dorofeev, O.N. Chernoplekov, V.E. Keylin, E.P. Volkov, Yu.G. Shakaryan, A.K. Mikhailov, V.E. Sytnikov, L.I. Chubrayev, N.L. Novikov, Problemy sozdaniya i primeneniya $\mathrm{V}$ elektricheskih setyah ustrojstv, ispol'zuyushchih yavleniya sverhprovodimosti [Problems of creation and application in electrical networks of devices using the phenomenon of superconductivity]. Electricity 7, 22-30 (2005) 